\title{
Kinerja Keuangan Berbasis Shari'ate Value Added Approach: Komparasi Antara Bank Umum Syariah Dan Unit Usaha Syariah Di Indonesia
}

\author{
Sri Wahyuni ${ }^{1}$, Pujiharto ${ }^{2}$ \\ Universitas Muhammadiyah Purwokerto \\ yuni_7067@yahoo.co.id
}

\begin{abstract}
This study aims to measure the financial performance of Islamic banking in Indonesia using Sharia Value Added Approach. In specific, objectives of this study is comparing financial performance between Islamic banks and sharia business unit that measure using sharia value added approach. The object of this study is islamic banking covers Islamic Banks and Sharia Business Unit, with research period is 2010-2015. Sample selection using purposive sampling method. Financial performance was measured in this study is Return on Asset (ROA), Return on Equity (ROE), Net Profit to Productive Asset (NPPA), and Net Profit Margin (NPM). The result of this study shows that financial performance of Islamic banking is healty. There are a significant differences of ROA, ROE, and NPPA between sharia commercial banking and sharia business unit that measure using sharia value added statement approach. But, NPM is not. The result of this study provides a significant contribution to developing Sharia Enterprise Theory. For manager of Islamic banking, Bank Indonesia and Sharia Financial Standard Board, the result of study can used to create policies related to measurement of Islamic Banking performance.
\end{abstract}

Keywords: financial performance, sharia value added approach, Islamic banks, sharia business unit

\begin{abstract}
ABSTRAK
Penelitian ini bertujuan untuk mengukur kinerja keuangan perbankan syariah di Indonesia dengan menggunakan Pendekatan Nilai Tambah Syariah. Secara spesifik, tujuan penelitian ini adalah membandingkan kinerja keuangan antara bank syariah dan unit usaha syariah yang diukur menggunakan pendekatan nilai tambah syariah. Objek penelitian ini adalah perbankan syariah meliputi Bank Syariah dan Unit Usaha Syariah, dengan periode penelitian 2010-2015. Pemilihan sampel menggunakan metode purposive sampling. Kinerja keuangan yang diukur dalam penelitian ini adalah ROA, ROE, NPPA, dan NPM. Hasil penelitian ini menunjukkan bahwa kine9rja keuangan perbankan syariah sehat. Ada perbedaan yang signifikan antara ROA, ROE, dan NPPA antara unit usaha perbankan syariah dan syariah yang diukur menggunakan pendekatan penilaian nilai tambah syariah. Akan tetapi,tidak dengan NPM. Hasil penelitian ini memberikan kontribusi yang signifikan terhadap pengembangan Teori Usaha Syariah. Bagi pengelola perbankan syariah, Bank Indonesia dan Dewan Standar Keuangan Syariah, hasil penelitian dapat digunakan untuk membuat kebijakan terkait pengukuran kinerja Perbankan Syariah.
\end{abstract}

Kata kunci: kinerja keuangan, pendekatan nilai tambah syariah, bank syariah, unit usaha syariah 


\section{PENDAHULUAN}

Sistem keuangan dan perbankan syariah merupakan bagian dari konsep yang lebih luas tentang ekonomi Islam, yang tujuannya adalah memberlakukan sistem nilai dan etika Islam ke dalam lingkungan ekonomi. Karena dasar etika inilah, maka perbankan Islam bagi kebanyakan Muslim, bukan sekedar sistem transaksi komersial. Persepsi Islam dalam transaksi finansial itu dipandang oleh banyak kalangan Muslim sebagai kewajiban agama. Kemampuan lembaga keuangan Islam menarik investor dengan sukses bukan hanya tergantung pada tingkat kemampuan lembaga itu menghasilkan keuntungan, tetapi juga pada persepsi bahwa lembaga tersebut secara sungguh-sungguh memperhatikan batasbatas yang digariskan oleh Islam.

Prinsip utama yang harus dikembangkan oleh bank syariah dalam meningkatkan kinerja keuangan adalah kemampuan bank syariah memberikan bagi hasil yang optimal kepada nasabah. Hal tersebut menunjukkan kemampuan bank syariah dalam melakukan pengelolaan dana. Penilaian kinerja keuangan bank syariah dapat dilakukan dengan menganalisa laporan keuangan yang diterbitkan. Analisis kinerja keuangan bisa dilakukan dengan mengukur tingkat profitabilitas bank syariah yang bersangkutan, dengan menggunakan empat rasio yaitu Return On Asset (ROA), Return On Equity (ROE), Net Profit Margin (NPM), dan Rasio Efisiensi Operasional (REO). Kualitas kinerja keuangan bank syariah, dapat dilihat seberapa besar rasio kinerja keuangan yang diperoleh. Semakin besar rasio yang diperoleh berarti kemampuan bank syariah dalam memberikan keuntungan bagi hasil kepada nasabah semakin baik, dan sebaliknya jika perolehan rasio kinerja keuangan kecil berarti kemampuan bank syariah memberikan keuntungan berupa bagi hasil kepada nasabah rendah.

Akan tetapi, fakta menunjukkan bahwa saat ini para pengguna laporan keuangan, seperti: nasabah, pemerintah, masyarakat dan manajemen dihadapkan pada kondisi dimana laporan keuangan bank syariah belum dapat dijadikan dasar analisa kinerja keuangan bank syariah secara tepat, mengingat laporan keuangan bank syariah sebagaimana termuat dalam Pernyataan Standar Akuntansi Keuangan (PSAK) No.101 (Standar Akuntansi Keungan, 2011) hanya memuat sejumlah elemen laporan keuangan sebagaimana elemen dalam laporan keuangan bank konvensional, ditambah dengan beberapa laporan seperti Laporan Perubahan Dana Investasi Terikat, Laporan Sumber dan Penggunaan Dana Zakat serta Laporan Sumber dan Penggunaan Dana Kebajikan. Selain itu di dalam Kerangka Dasar Penyusunan dan Penyajian Laporan Keuangan Bank Syariah disebutkan bahwa tujuan akuntansi keuangan bank syariah adalah penyediaan informasi keuangan ditambah seputar informasi yang berkaitan dengan prinsip syariah, yang merupakan karakteristik dari bank syariah (Rifai, 2013). Jika dikaji secara lebih lanjut, maka dapat disimpulkan bahwa tujuan laporan keuangan bank syariah masih berorientasi pada kepentingan direct stakeholders. 
Mengingat bank syariah adalah unit usaha bisnis yang berdasarkan syariat Islam, maka seyogyanya akuntansi keuangan yang digunakan adalah akuntansi syariah. Tujuan akuntansi syariah tidak hanya sebatas menyediakan informasi yang berkaitan dengan pengambilan keputusan ekonomi saja, akan tetapi sebagaimana diungkapkan oleh para pakar akuntansi syariah, tujuan akuntansi syariah adalah mu'amalah yaitu Amar Ma'ruf Nahi Munkar, keadilan dan kebenaran, maslahat sosial, kerjasama, menghapus riba, dan mendorong zakat (Mulawarman, 2009). Dengan demikian, tujuan akuntansi syariah lebih menekankan pentingnya memberikan informasi bagi penghitungan zakat, pelaksanaan keadilan dan melaporkan kegiatan yang bertentangan dengan syariah. Tujuan-tujuan tersebut perlu dilakukan dalam rangka memenuhi tanggungjawab bank kepada direct stakeholders maupun indirect stakeholders (Wahyudi, 2005).

Lebih lanjut, dalam kaitannya dengan pemenuhan akuntabilitas laporan keuangan bank syariah, Baydoun dan Willet (2000), seorang pakar akuntansi syariah merekomendasikan laporan nilai tambah (Value Added Statement), sebagai tambahan dalam laporan keuangan bank syariah. Laporan nilai tambah menurut Baydoun dan Willet (2000), merupakan laporan keuangan yang lebih menekankan prinsip full disclosure dan didorong akan kesadaran moral dan etika. Karena prinsip full disclosure merupakan cerminan kepekaan manajemen terhadap proses aktivitas bisnis terhadap pihak-pihak yang terlibat di dalamnya. Kepekaan itu terwujud berupa penyajian informasi akuntansi melalui distribusi pendapatan secara lebih adil. Adanya laporan nilai tambah telah mengubah mainstream tujuan akuntansi dari decision making bergeser kepada pertanggungjawaban sosial, yang sejalan dengan tujuan akuntansi syariah.

Berdasarkan pada penjelasan di atas, maka penelitian ini penting untuk dilakukan, karena penerapan sharia enterprise theory pada bank syariah akan mendorong kesesuaian antara antara tujuan dan praktik akuntansi syariah dengan tujuan hidup manusia sebagai hamba Allah. Dengan menerapkan syariah value added approach akan diperoleh informasi yang sesungguhnya mengenai nilai perusahaan, ketepatan dan keakuratan nilai serta kerjasama didalamnya, sehingga kinerja keuangan yang dihasilkan dapat diukur secara riil.

Pada artikel sebelumnya yang dilakukan Wahyuni dan Pujiharto, (2017) memberikan bukti empiris bahwa penerapan syariah enterprise theory pada bank umum syariah dalam bentuk pengukuran kinerja keuangan berbasis syari'ate value added menyajikan kinerja keuangan yang berbeda dengan pengukuran kinerja keuangan berbasis income statement approach. Sehingga informasi kinerja keuangan yang disajikan bank syariah mencerminkan nilai perusahaan yang sesungguhnya. Pada artikel ini akan diperluas sampel, tidak hanya bank umum syariah, tetapi mencakup juga unit usaha syariah, sekaligus menguji apakah terdapat perbedaan yang signifikan kinerja keuangan, yang diukur dengan 
pendekatan syari'ate value added antara bank umum syariah dan unit usaha syariah.

\section{TINJAUAN PUSTAKA DAN PENGEMBANGAN HIPOTESIS Perbankan Syariah}

Bank Syariah adalah suatu lembaga keuangan yang fungsi utamanya menghimpun dana untuk disalurkan kepada orang atau lembaga yang membutuhkannya dengan sistem tanpa bunga. Di Indonesia pelopor perbankan syariah adalah Bank Muamalat Indonesia (BMI). BMI berdiri tahun 1991, yang diprakarsai oleh Majelis Ulama Indonesia (MUI) dan pemerintah serta dukungan dari Ikatan Cendekiawan Muslim Indonesia (ICMI) serta beberapa pengusaha muslim. Saat ini keberadaan bank syariah di Indonesia telah di atur dalam Undang-undang yaitu UU No. 10 tahun 1998 tentang Perubahan UU No. 7 tahun 1992 tentang Perbankan, dan yang terbaru UU No.21 tahun 2008. Hingga tahun 2015 terdapat 12 institusi bank syariah di Indonesia. Sementara itu bank umum yang telah memiliki Unit Usaha Syariah adalah 24 bank (Statistik Perbankan Syariah, 2015).

Pada dasarnya produk yang ada pada perbankan syariah sama dengan produk yang ada pada perbankan konvensional, yakni terdiri dari produk penghimpunan dana (funding), produk penyaluran dana (lending), dan produk jasa (fee based product). Adapun yang membedakannya adalah bahwa pada produk yang ada di bank syariah tidak boleh mengandung unsur-unsur yang secara tegas dilarang dalam Islam, yaitu unsur perjudian (maisyir), unsur ketidakpastian (gharar), unsur bunga (riba), unsur suap-menyuap (rysiwah), dan unsur bathil. Sebagai gantinya dapat diterapkan akad-akad tradisional Islam atau yang lazim disebut prinsip syariah ke dalam produk perbankan dimaksud (Muhammad, 2005).

\section{Perbedaan Bank Umum Syariah dan Unit Usaha Syariah}

Menurut UU No No.21 tahun 2008 tentang perbankan Syariah, pengertian Bank Umum Syariah adalah bank syariah yang dalam kegiatannya memberikan jasa melalui lalu lintas pembayaran. Sedangkan pengertian Unit Usaha Syariah adalah unit kerja dari kantor pusat bank konvensional yang berfungsi sebagai kantor induk dari kantor atau unit yang melaksanakan kegiatan usaha berdasarkan prinsip syariah, atau unit kerja di kantor cabang dari suatu bank yang berkedudukan di luar negeri yang melaksanakan usaha secara konvensional yang berfungsi sebagai kantor induk dari kantor cabang pembantu syariah dan/atau unit syariah. Sedangkan perbedaan antara BUS dan UUS adalah sebagai berikut:

\section{Bank Umum Syariah}

Pendirian bank umum syariah baru wajib memenuhi persyaratan permodalan sebagai berikut: 
1. Jumlah modal disetor minimal sebesar Rp. 1 trilyun. Bagi bank asing yang membuka kantor cabang syariah dana disetor minimal Rp. 1 trilyun, yang dapat berupa rupiah atau valuta asing.

2. Sumber dana modal disetor untuk pendirian bank umum baru tidak boleh berasal dari dana pinjaman atau fasilitas pembiayaan dalam bentuk apapun dari bank atau pihak lain di Indonesia.

3. Sumber dana modal disetor untuk bank baru tersebut tidak boleh berasal dari sumber yang diharamkan menurut ketentuan syariah termasuk dari dan tujuan pencucian uang (money laundering).

\section{Unit Usaha Syariah}

Bank umum konvensional yang melakukan kegiaan usaha berdasarkan prinsip syariah wajib membuka UUS.

1. Pembukaan UUS hanya dapat dilakukan dengan izin Bank Indonesia.

2. Modal kerja UUS merupakan modal yang disisihkan dalam suatu rekening tersendiri yang dapat digunakan untuk membiayai kegiatan operasional dan non operasional kantor cabang syariah.

3. Besarnya modal kerja minimal sebesar Rp 100.000.000.000,- (seratus miliar rupiah).

4. Penyisihan modal kerja UUS dari kantor induknya, dimaksudkan agar pengelolaannya tidak tercampur dengan dana kantor induknya yang beroperasional secara konvensional

\section{Sharia Enterprise Theory}

Pengembangan model Syari'ate Value Added Approach didasarkan pada Syariah Enterprise Theory (SET) yang dikemukakan oleh Triyuwono (2002) yang dikembangkan berdasarkan pada metafora zakat yang berkarakter keseimbangan. SET tidak mendudukkan manusia sebagai pusat dari segala sesuatu seperti yang dipahami dalam antrosentrisme, akan tetapi menempatkan Tuhan sebagai pusat dari segala sesuatu. Tuhan menjadi pusat kembalinya manusia dan alam semesta. Oleh karena itu manusia di muka bumi ini hanya sebagai wakil Tuhan yang mempunyai konsekuensi patuh pada hukum-hukum Tuhan, sehingga kesejehteraan hanya semata-mata dikonsentrasikan pada stackholders. Zakat (yang kemudian dimetaforakan menjadi metafora zakat) secara implisit mengandung nilai egoistik-altruistik, materi-spritual, dan individu-jamaah. Konsekuensi dari diterimanya syariah enterprise theory sebagai dasar pengembangan akuntansi syariah adalah pengakuan income dalam bentuk nilai tambah (value added) bukan income dalam pengertian laba (profit) seperti yang diadopsi dalam entity theory (Triyuwono et al, 2006; Mulawarman, 2009, Rifai, 2013)

\section{Konsep Value Added Aproach}

Value Added Statement (VAS) atau Laporan Nilai Tambah berkaitan juga dengan Akuntansi Sumber Daya Manusia (Human Resources Accounting) dan 
Employee Reporting terutama dalam hal informasi yang disajikan. Value Added Statement ini mangatasi kekurangan informasi yang disajikan dalam laporan keuangan utama, Neraca, Laba Rugi, dan Arus Kas. Karena semua laporan ini gagal memberikan informasi mengenai: 1) Total produktivitas dari perusahaan; 2) Share dari setiap stakeholders atau anggota tim yang ikut dalam proses manajemen, yaitu: pemegang saham, kreditur, pegawai, masyarakat dan pemerintah (Mulawarman et al, 2006).

VAS berusaha untuk mengatasi kekurangan ini selain memberikan informasi tentang kompensasi yang diberikan kepada pegawai dan mereka yang berkepentingan (stakeholders) lainnya terhadap informasi perusahaan. Jika laporan keuangan konvensional menekankan informasinya pada laba maka VAS menekankan pada upaya menghasilkan kekayaan. Karena laba pemegang saham (kapitalis) biasanya hanya menggambarkan hak atau kepentingan pemegang saham saja bukan seluruh tim yang ikut terlibat dalam kegiatan perusahaan.

Value added adalah kenaikan nilai kekayaan yang dihasilkan dengan penggunaan yang produktif dari seluruh sumber-sumber kekayaan perusahaan oleh seluruh tim yang ada termasuk pemilik modal, karyawan, kreditor, dan pemerintah. Value added tidak sama dengan laba. Laba menunjukkan pendapatan bagi pemilik saham sedangkan nilai tambah mengukur kenaikan kekayaan bagi seluruh stakeholders.

VAS ini merupakan alternatif pengganti laporan laba rugi dalam akuntansi konvensional. Baydoun dan Willet (2000) menjelaskan bahwa VAS merupakan laporan keuangan yang lebih menerapkan prinsip full disclosure dan didorong dengan kesadaran moral dan etika. Karena prinsip full disclosure paling tidak mencerminkan kepekaan manajemen terhadap proses aktivitas bisnis terhadap pihak-pihak yang terlibat didalamnya, sehingga kepekaan itu diwujudkan dalam informasi akuntansi melalui distribusi pendapatan yang lebih adil. Artinya bahwa dengan VAS perusahaan telah merubah mainstream tujuan akuntansinya dari decision making yang kabur bergeser ke pertanggungjawaban sosial. Konsep VAS merupakan salah satu bukti pelaporan yang menggambarkan nilai-nilai Islam (Mulawarman et al, 2006; Fauzi, 2012, Rifai, 2013)

Dengan menerapkan VAS keselarasan dengan prinsip syariah yaitu keadilan, kejujuran, full disclosure dan pertanggungjawaban dapat terwujud. Lebih lanjut, VAS dikonstruksi sebagai wujud dari kesatuan tujuan perusahaan yang tidak hanya pada sosial, tetapi juga pertanggungjawaban kepada Pencipta. Artinya tujuan laporan keuangan tersebut menjadi media pertanggungjawaban manajemen secara vertikal dan horisontal. Dengan penetapan tujuan ini maka diharapkan tidak ada bias antara tujuan dan praktek akuntansi dengan tujuan hidup kita sebagai hamba Allah (Mulawarman, 2009). 


\section{Pengembangan Hipotesis}

Hipotesis penelitian ini dirumuskan berdasarkan konseptual teori dan juga didasarkan pada hasil temuan empiris pada penelitian sebelumnya.Hipotesis yang akan diuji dalam penelitian ini adalah sebagai berikut:

\section{Hipotesis Perbedaan Rasio Return On Asset (ROA) antara Bank Umum} Syariah dan Unit Usaha Syariah

Return On Asset (ROA) menunjukkan kemampuan perusahaan dalam menghasilkan keuntungan, dari seluruh asset atau kekayaan yang dimilikinya. Semakin besar rasio ROA suatu bank maka semakin besar tingkat keuntungan yang dicapai bank tersebut dan semakin baik pula posisi bank tersebut dari sisi penggunaan asset. Hasil penelitian Kurniasari (2015) menemukan bukti empiris bahwa terdapat perbedaan yang signifikan rasio ROA antara BUS dan UUS pada perbankan syariah di Indonesia. Berdasarkan uraian tersebut diatas, maka dirumuskan hipotesis sebagai berikut:

H1: Terdapat perbedaan yang signifikan pada rasio ROA antara BUS dan UUS

Hipotesis Perbedaan Rasio Return On Equity (ROE) antara Bank Umum Syariah dan Unit Usaha Syariah

Return On Equity merupakan rasio yang digunakan untuk mengukur kemampuan bank memperoleh laba dan efisiensi secara keseluruhan operasional melalui penggunaan modal sendiri. Rasio ini diperoleh dengan membagi laba tahun berjalan dengan total modal. Rasio ROE merupakan indikator penting bagi pemegang saham dan calon investor untuk mengukur kemampuan bank dalam memperoleh laba bersih yang dikaitkan dengan pembayaran deviden. Semakin tinggi ROE maka semakin tinggi pula laba yang diperoleh perusahaan sehingga rentabilitas bank semakin baik (Rahmawati, 2008). Diduga, terdapat perbedaan yang signifikan rasio ROE antara BUS dan UUS, mengingat terdapat perbedaan karakteristik terkait dengan perrmodalan antara BUS dan UUS. Berdasarkan uraian tersebut diatas, maka dirumuskan hipotesis sebagai berikut:

H2: Terdapat perbedaan yang signifikan pada rasio ROE antara BUS dan UUS

Hipotesis Perbedaan Rasio Laba Bersih dan Total Aktiva Produktif antara Bank Umum Syariah dan Unit Usaha Syariah

Value Added Statement yang jika dalam akuntansi konvensional disebut dengan Laporan Laba Rugi, namun dari keduanya terdapat perbedaan. Value Added Statement lebih menekankan pada distribusi nilai tambah yang diciptakannya kepada pihak-pihak yang berhak menerimanya.

Laba merupakan kelebihan penghasilan diatas biaya selama satu periode akuntansi. Laba tidak sama dengan nilai tambah. Laba menunjukan pendapatan bagi pemilik saham, sedangkan nilai tambah mengukur kenaikan kekayaan bagi seluruh stakeholders (Harahap, 2006).

Pengertian aktiva produktif adalah penanaman dana bank baik dalam rupiah maupun valuta asing dalam bentuk kredit, surat berharga, penempatan dana antar 
bank, penyertaan, komitmen dan kontijensi pada transaksi rekening administratif (Rindawati, 2003). Rasio ini digunakan untuk mengetahui kemampuan bank dalam mengelola dana yang diinvestasikan dalam keseluruhan aktiva produktif. Diduga, terdapat perbedaan yang signifikan rasio LBAP antara BUS dan UUS, karena perbedaan karakteristik BUS dan UUS. Sehingga hipotesis ketiga yang dikembangkan adalah:

H3: Terdapat perbedaan yang signifikan pada rasio perbandingan antara total laba bersih dengan total aktiva produktif antara BUS dan UUS.

Hipotesis Perbedaan Rasio NPM antara Bank Umum Syariah dan Unit Usaha Syariah

Net Profit Margin (NPM) merupakan rasio yang digunakan untuk mengukur kemampuan bank dalam menghasilkan net income dari kegiatan operasi pokoknya. Untuk mencari besarnya net profit margin dengan cara membagi besarnya net income dengan operating income kemudian dikalikan dengan $100 \%$. Semakin tinggi rasio NPM suatu bank, hal itu menunjukan hasil yang semakin baik. Sebaliknya jika hasil rasio NPM semakin rendah, maka menunjukan hasil yang semakin buruk.

Penelitian Sulastri (2010) tidak ada di daftar pustaka yang menghitung rasio NPM berdasarkan pendekatan laba bersih membuktikan bahwa kemampuan bank syariah dalam menghasilkan laba bersih mengalami peningkatan. Peningkatan ini disebabkan oleh adanya peningkatan jumlah pendapatan dan laba, sedangkan rasio NPM yang dihitung dengan pendekatan nilai tambah, maka perhitungannya pun berbeda. Sehingga hipotesis keempat yang akan diuji adalah sebagai berikut:

H4: Terdapat perbedaan yang signifikan pada rasio NPM bank syari'ah jika dianalisis dengan pendekatan nilai tambah antara BUS dan UUS

\section{METODE PENELITIAN}

\section{Populasi dan Sampel Penelitian}

Populasi dalam penelitian ini adalah bank syariah yang beroperasi di Indonesia periode tahun 2010 sampai dengan tahun 2015, baik yang berstatus Bank Umum Syariah (BUS) maupun Unit Usaha Syariah (UUS).

\section{Metode Pengambilan Sampel}

Metode pengambilan sampel dalam penelitian ini adalah metode purposive sampling, yaitu pengambilan sampel sesuai kriteria yang telah ditetapkan. Kriteria tersebut adalah: 1) Laporan keuangan Bank Umum Syariah dan UUS periode 2010-2015; 2) Semua variabel tersedia secara lengkap pada periode penelitian.

\section{Jenis dan Sumber Data}

Data yang digunakan dalam penelitian ini adalah data sekunder. Dalam penelitian ini data sekunder yang digunakan adalah laporan keuangan bank syariah. Dari laporan keuangan kita dapat mengukur kinerja keuangan bank syariah, meliputi: ROA, ROE, LBAP dan NPM. Data ini bersumber dari Bursa 
Efek Indonesia (BEI), Bank Indonesia (BI) serta database Statistik Perbankan Syariah.

\section{Metode Pengumpulan Data}

Metode pengumpulan data yang digunakan dalam penelitian ini adalah dokumentasi, yang dilakukan dengan cara mendokumentasikan data-data penelitian yang dibutuhkan.

\section{Variabel Penelitian dan Definisi Operasional}

Variabel yang digunakan dalam penelitian ini adalah kinerja keuangan bank syariah.

X1: kinerja keuangan BUS adalah gambaran mengenai kemampuan kinerja BUS dalam menghasilkan nilai tambah

X2: kinerja keuangan UUS adalah gambaran mengenai kemampuan kinerja UUS dalam menghasilkan nilai tambah.

Kinerja keuangan yang akan diukur meliputi rasio-rasio:

\section{Return On Asset (ROA)}

ROA mengukur kemampuan manajemen bank dalam memperoleh keuntungan (laba) secara keseluruhan. Semakin tinggi rasio ROA, semakin besar pula tingkat keuntungan yang dicapai bank dan semakin baik pula posisi bank dari segi penggunaan asset. Berikut adalah pengukuran ROA dan kriteria kesehataan bank:

$\mathrm{ROA}=\frac{\text { Nilai Tambah }}{\text { Total Aktiva }} \times 100$ (shari'ate value added approach)

Kriteria: < $1 \%$, sangat rendah; > $1 \%-1,9 \%$ rendah; > $2 \%-3 \%$ tinggi; > $3 \%$ sangat tinggi

\section{Return on Equity (ROE)}

ROE merupakan rasio yang mengukur kemampuan bank dalam menghasilkan laba bersih dari modal sendiri yang digunakan oleh bank. Dari sudut pandang pemilik modal, ROE merupakan ukuran yang lebih penting karena merefleksikan kepentingan mereka. ROE diukur sebagai berikut:

$\mathrm{ROE}=\frac{\text { Nilai Tambah }}{\text { Modal Sendiri }} \times 100$ (shari'ate value added approach)

Kriteria: $\mathrm{ROE} \geq 12 \%$ Sehat; $\mathrm{ROE} \leq 12 \%$ tidak sehat

\section{Rasio Laba Bersih Aktiva Produktif (LBAP)}

Rasio LBAP digunakan untuk mengetahui kemampuan bank dalam mengelola dana yang diinvestasikan dalam keseluruhan aktiva produktif (Rifai, 2013). Rumus yang digunakan adalah:

LBAP $=\frac{\text { Nilai Tambah }}{\text { Total Aktiva Produktif }} \times 100$ (shari'ate value added approach)

Kriteria: : $0,00 \%$ - $\leq 10,35 \%$ : sehat; $10,36 \%$ - $\leq 12,60 \%$ : cukup sehat; $12,61 \%$ $\leq 14,85 \%$ : Kurang sehat; $<0,76 \%$ tidak sehat. 


\section{Net Profit Margin (NPM)}

NPM mengukur efisiensi bank dalam menghasilkan laba bersih sebelum pajak (net income) ditinjau dari sudut pendapatan operasinya. Semakin tinggi rasio NPM semakin efisien bank dalam menghasilkan laba.

$$
\mathrm{NPM}=\frac{\text { Nilai tambah }}{\text { Pendapatan Operasional }} \times 100 \text { (shari'ate value added approach) }
$$

Kriteria: NPM $\geq 5 \%$ :Sehat; $3 \% \leq \mathrm{NPM} \leq 5 \%$ : Cukup Sehat; NPM $\leq 3 \%$ : Kurang Sehat

\section{Teknik Analisis Data}

Langkah-langkah analisis yang dilakukan adalah sebagai berikut: 1) Menyusun Syari'ate Value Added Statement; 2) Menghitung rasio-rasio keuangan didasarkan pada Syari'ate Value Added Statement yang telah tersusun. 3) Melakukan analisis diskriptif ; 4) Melakukan uji beda (t-test); 5) Membuat kesimpulan dan saransaran bagi manajemen bank syariah.

\section{Hasil Pemilihan Sampel Penelitian}

Dari hasil pengumpulan data penelitian diperoleh data mengenai laporan keuangan dan laporan tahunan Bank Umum Syariah dan Unit Usaha Syariah periode 2010-2015. Sumber data penelitian diperoleh dari Bank Indonesia dan Statistik Perbankan Syariah Indonesia serta website bank syariah di Indonesia. Sampel yang diperoleh ditunjukkan pada tabel 1 berikut:

Tabel 1 Proses Pemilihan Sampel Penelitian

\begin{tabular}{lc}
\hline Bank Umum Syariah yang beroperasi tahun 2015 & 11 \\
Dikurangi: Bank umum syariah yang tidak mempunyai data lengkap & 1 \\
Bank Umum Sariah yang menjadi sampel penelitian & 10 \\
Unit Usaha Syariah yang beroperasi tahun 2015 & 22 \\
Dikurangi: unit usaha syariah yang tidak mempunyai data lengkap & 12 \\
Unit Usaha Syariah yang menjadi sampel penelitian & 10 \\
Total sampel penelitian & 20 \\
Total data sampel 20 x 6 periode penelitian (2010-2015) & 120 \\
\hline
\end{tabular}

Tabel 2. Daftar Perbankan Syariah yang menjadi Sampel Penelitian

\begin{tabular}{lll}
\hline \multicolumn{3}{c}{ Perbankan Syariah di Indonesia } \\
\hline No. & \multicolumn{1}{c}{ Nama Bank Umum Syariah } & \multicolumn{1}{c}{ Nama Unit Usaha Syariah } \\
\hline 1. & BCA Syariah & Bank Danamon Syariah \\
2. & BNI Syariah & Bank International Indonesia Syariah \\
3. & BRI Syariah & Bank Pembangunan Daerah Daerah Istemawa \\
& & Jogyakarta Syariah \\
4. & Bank MayBank Syariah Indonesia & Bank Permata Syariah \\
5. & Bank Muammalat Indonesia & Bank Sinarmas Syariah \\
6. & Bank Panin Syariah & Bank Pensiunan dan Tabungan Nasional \\
& & Syariah \\
7. & Bank Syariah Bukopin & Bank DKI Syariah \\
\hline
\end{tabular}




\begin{tabular}{lll}
\hline 8. & Bank Syariah Mandiri & Bank Jateng Syariah \\
& & \\
9. & Bank Syaria Mega Indonesia & Bank Jatim Syariah \\
10. & Bank Victoria Syariah & Bank NISP Syariah \\
\hline
\end{tabular}

Sumber: Statistik Perbankan Syariah, 2015

\section{Perkembangan Rata-rata Rasio Keuangan Bank Umum Syariah dengan Pendekatan Nilai Tambah tahun 2010-2015}

Perkembangan rata-rata rasio keuangan Bank Umum Syariah dengan pendekatan syari'ate value added approach ditunjukkan pada tabel 3.berikut ini:

Tabel 3. PerkembanganRata-rata Rasio Keuangan Bank Umum Syariah

Pendekatan Nilai Tambah (VAS) tahun 2010-2015

\begin{tabular}{lcccccc}
\hline \multicolumn{7}{c}{ Value Added Statement Approach } \\
\hline Tahun & 2010 & 2011 & 2012 & 2013 & 2014 & 2015 \\
& & & & & & \\
\hline ROA (\%) & 2,41 & 5,29 & 3,92 & 4,24 & 3,66 & $-1,26$ \\
ROE (\%) & 26,51 & 41,40 & 75,84 & 39,92 & 32,22 & 915 \\
LBAP (\%) & 10,35 & 1,95 & 1,11 & 1,14 & 0,91 & 1,02 \\
NPM (\%) & 29,25 & 55,42 & 42,78 & 49,57 & 40,73 & $-21,31$ \\
\hline
\end{tabular}

Tabel 3 menunjukkan bahwa rasio keuangan Bank Umum Syariah dari tahun 2010-2015 mengalami perkembangan yang fluktuatif. Rata-rata rasio ROA BUS meningkat dari 2,41\% di tahun 2010 menjadi 5,29\% di tahun 2011. Tahun 2012 turun menjadi 3,92\% dan meningkat lagi di tahun 2013menjadi 4,24\%. Akan tetapi menurun di tahun 2014 menjadi 3,66\%. Pada tahun 2015 ROA BUS mengalami penurunan rasio yang cukup drastis, yaitu di angka -1,26. Perkembangan yang fluktuatif juga terjadi pada rata-rata rasio yang lain, yaitu ROE, NPM dan LBAP.

\section{Perkembangan Rata-rata Rasio Keuangan Unit Usaha Syariah dengan Pendekatan Nilai Tambah (VAS) tahun 2010-2015}

Perkembangan rata-rata rasio keuangan Unit Usaha Syariah dengan pendekatan sharia'ate value added approach ditunjukkan pada tabel 4 berikut ini: Tabel 4. Perbandingan Rata-rata Rasio Keuangan Unit Usaha Syariah dengan Pendekatan Laporan Laba Rugi (ISA) dan Pendekatan Nilai Tambah (VAS) tahun 2010-2015

\begin{tabular}{lcccccc}
\hline \multicolumn{7}{c}{ Value Added Statement Approach } \\
\hline Tahun & 2010 & 2011 & 2012 & 2013 & 2014 & $\mathbf{2 0 1 5}$ \\
& & & & & & \\
\hline ROA (\%) & 0,90 & $-3,57$ & 0,45 & 3,63 & $-0,37$ & 1,18 \\
ROE (\%) & 2,98 & $-3,57$ & 1,15 & 6,67 & $-1,21$ & 2,93 \\
LBAP (\%) & 0,75 & $-5,14$ & 0,51 & 4,17 & $-0,26$ & 1,18 \\
NPM (\%) & 5,78 & $-11,16$ & 4,78 & 6,95 & 4,39 & 22,73 \\
\hline
\end{tabular}

Tabel 4 menunjukkan bahwa rasio keuangan unit usaha syariah dari tahun 2010-2015 juga mengalami perkembangan yang fluktuatif, seperti halnya BUS, yang dihitung dengan pendekatan syari'ate value added statement. Rata-rata rasio ROA UUS menurun dari 0,90 \% di tahun 2010 menjadi -3,57\% di tahun 2011. 
Tahun 2012 meningkat menjadi 0,45\% dan meningkat yang cukup signifikan di tahun 2013 menjadi 3,63\%. Akan tetapi menurun di tahun 2014 menjadi $-0.37 \%$. Pada tahun 2015 rasio ROA UUS mengalami peningkatan lagi yaitu di angka 1,18. Perkembangan yang fluktuatif juga terjadi pada rata-rata rasio yang lain, yaitu ROE, NPM dan LBAP.

\section{HASIL ANALISIS STATISTIK DESKRIPTIF}

Analisis deskriptif dimaksudkan untuk melihat karakteristik data, dimana dalam penelitian ini menggunakan rata-rata, nilai minimum, nilai maksimum dan standar deviasi dari masing- masing rasio antara BUS dan UUS. Hasil analisis statistik deskriptif dilihat pada Tabel 5.

Tabel 5. Statistik Deskriptif Rasio Keuangan Perbankan Syariah di Indonesia berbasis SVAS Periode 2010-2015

\begin{tabular}{lcccc}
\hline & Bank Umum Syariah & & \\
& ROA & ROE & NPM & LBAP \\
\hline Rata-rata & 1,54 & 10,36 & 7,78 & 0,89 \\
Minimum & 0,08 & 0,44 & 0,80 & 0,08 \\
Maksimum & 4,48 & 32,87 & 18,84 & 2,71 \\
Standar Deviasi & 1,07 & 9,29 & 0,89 & 0,75 \\
\hline & Unit Usaha Syariah & & & \\
& ROA & ROE & NPM & LBAP \\
\hline Rata-rata & 4,49 & 13,24 & 0,44 & 5,63 \\
Minimum & 0,24 & 2,90 & 0,01 & 0,08 \\
Maksimum & 13,34 & 47,55 & 0,14 & 15,54 \\
Standar Deviasi & 3,54 & 10,71 & 0,037 & 4,52 \\
\hline
\end{tabular}

Dari tabel 5 pada BUS menunjukkan bahwa variabel ROA memiliki nilai rata-rata sebesar 1,54, nilai minimum 0,08 dan nilai maksimum 4,48 dengan standar deviasi sebesar 1,07. Dari data tersebut terlihat bahwa standar deviasi lebih rendah dari rata-ratanya yang berarti ada variasi pada rasio ROA. Hal ini mengindikasikan bahwa efektivitas perusahaan dalam memanfaatkan besarnya aset yang dimiliki untuk menciptakan laba adalah baik sehingga nilai ROA menjadi besar. Sedangkan pada pendekatan UUS menunjukkan bahwa variabel ROA memiliki nilai rata-rata sebesar 4,49, nilai minimum 0,24 dan nilai maksimum 13,34 dengan standar deviasi sebesar 3,54. Dari data tersebut terlihat bahwa standar deviasi lebih rendah dari rata-ratanya yang berarti ada variasi pada rasio ROA. Hal ini mengindikasikan bahwa efektivitas perusahaan dalam memanfaatkan besarnya aset yang dimiliki untuk menciptakan nilai tambah adalah baik sehingga nilai ROA menjadi besar.

Variabel NPM pada BUS memiliki nilai rata-rata sebesar 7,78, nilai minimum 0,80 dan nilai maksimum 18,84 dengan standar deviasi sebesar 0,89. Dari data tersebut terlihat bahwa standar deviasi lebih rendah dari rata-ratanya yang berarti ada variasi pada rasio NPM. Hal ini mengindikasikan bahwa efektivitas perusahaan dalam memperoleh pendapatan operasional adalah baik 
sehingga laba bersih yang diperoleh tinggi Sedangkan pada UUS menunjukkan bahwa variabel NPM memiliki nilai rata-rata sebesar 0,44 , nilai minimum 0,01 dan nilai maksimum 0,14 dengan standar deviasi sebesar 0,037. Dari data tersebut terlihat bahwa standar deviasi lebih rendah dari rata-ratanya yang berarti ada variasi pada rasio NPM. Hal ini mengindikasikan bahwa efektivitas perusahaan dalam memperoleh pendapatan operasional adalah baik sehingga nilai tambah yang diperoleh tinggi.

Variabel LBAP pada BUS memiliki nilai rata-rata sebesar 0,89 nilai minimum 0,08 dan nilai maksimum 2,71 dengan standar deviasi sebesar 0,75. Dari data tersebut terlihat bahwa standar deviasi lebih rendah dari rata-ratanya yang berarti ada variasi pada rasio LBAP. Hal ini mengindikasikan bahwa efektivitas perusahaan dalam memanfaatkan besarnya aset produktif yang dimiliki untuk menciptakan laba adalah baik sehingga nilai LBAP menjadi besar. Sedangkan pada UUS menunjukkan bahwa variabel LBAP memiliki nilai rata-rata sebesar 4,49, nilai minimum 0,24 dan nilai maksimum 13,34 dengan standar deviasi sebesar 3,54. Dari data tersebut terlihat bahwa standar deviasi lebih rendah dari rata-ratanya yang berarti ada variasi pada rasio LBAP. Hal ini mengindikasikan bahwa efektivitas perusahaan dalam memanfaatkan besarnya aset produktif yang dimiliki untuk menciptakan nilai tambah adalah baik sehingga nilai LBAP menjadi besar.

\section{HASIL PENGUJIAN HIPOTESIS}

Pengujian hipotesis dalam penelitian ini menggunakan independent sample t test. Hasil pengujian hipotesis ditunjukkan pada tabel 6 berikut:

Tabel 6. Hasil Uji Beda Rasio Keuangan Berbasis VAS antara BUS dan UUS

\begin{tabular}{|c|c|c|c|c|}
\hline Variabel & t-hitung & Sig (2 tailed) & Keterangan & Kesimpulan \\
\hline ROA & 2,261 & 0,036 & $\mathrm{P}<0,05$ & $\begin{array}{l}\text { Berbeda } \\
\text { (H1 diterima) }\end{array}$ \\
\hline ROE & 4,010 & 0,000 & $\mathrm{P}<0,05$ & $\begin{array}{l}\text { Berbeda } \\
\text { (H2 diterima) }\end{array}$ \\
\hline NPM & 2,659 & 0,009 & $\mathrm{P}<0,05$ & $\begin{array}{l}\text { Berbeda } \\
\text { (H3 diterima) }\end{array}$ \\
\hline LBAP & 1,246 & 0,2 & $P>0,05$ & $\begin{array}{l}\text { Tidak Berbeda } \\
\text { (H4 ditolak) }\end{array}$ \\
\hline
\end{tabular}

\section{Hasil Pengujian Hipotesis Pertama (H1)}

Dari tabel 6 nilai t pada equal variance assumed adalah 2,261 dengan probabilitas signifikan 0,0,036 < 0,05 maka dapat disimpulkan bahwa rasio ROA pada BUS dan UUS adalah berbeda secara signifikan. Hal ini berarti bahwa hipotesis pertama yang menyatakan bahwa terdapat perbedaan yang signifikan rasio ROA antara BUS dan UUS jika dihitung dengan pendekatan value added approach, diterima.

\section{Hasil Pengujian Hipotesis Kedua (H2)}

Dari tabel 6 nilai t pada equal variance assumed adalah 4,010 dengan probabilitas signifikan $0,000<0,05$ maka dapat disimpulkan bahwa rasio ROE 
pada BUS dan UUS adalah berbeda. Hal ini berarti bahwa hipotesis kedua yang menyatakan bahwa terdapat perbedaan yang signifikan rasio ROE antara BUS dan UUS yang dihitung dengan pendekatan value added approach, diterima.

\section{Hasil Pengujian Hipotesis Ketiga (H3)}

Dari tabel 6 nilai t pada equal variance assumed adalah 2,659 dengan probabilitas signifikan 0,009 > 0,05 maka dapat disimpulkan bahwa rasio NPM antara BUS dan UUS adalah berbeda. Hal ini berarti bahwa hipotesis ketiga yang menyatakan bahwa terdapat perbedaan yang signifikan rasio NPM antara BUS dan UUS jika dihitung dengan pendekatan value added approach, ditolak.

\section{Hasil Pengujian Hipotesis Keempat (H4)}

Dari tabel 6 nilai t pada equal variance assumed adalah 1,256 dengan probabilitas signifikan 0,200>0,05 maka dapat disimpulkan bahwa rasio LBAP pada BUS dan UUS adalah sama. Hal ini berarti bahwa hipotesis keempat yang menyatakan bahwa terdapat perbedaan yang signifikan rasio LBAP antara BUS dan UUS jika dihitung dengan pendekatan value added approach, ditolak.

\section{KESIMPULAN, KETERBATASAN DAN SARAN}

Perkembangan rata-rata rasio keuangan bank syariah mengalami fluktuasi dari tahun 2010-2015. Terdapat perbedaan yang signifikan rasio keuangan ROA, ROE dan NPM antara BUS dan UUS jika dihitung syari'ate value added approach. Tidak terdapat perbedaan yang signifikan rasio keuangan LBAP perbankan syariah jika dihitung dengan syari'ate value added approach. Pendekatan Syari'ate Value Added Statement merupakan metode yang lebih baik dalam mengukur kinerja keuangan bank syariah karena pendekatan ini didasarkan pada Sharia Enterprise Theory, yang berfokus pada kesimbangan dunia dan akhirat. Implikasi dari penelitian ini adalah sebagai berikut: 1) para manajer dan pengelola UUS hendaknya menyusun laporan syari'ate value added statement disamping income statement, seperti halnya BUS; 2) Para pengguna laporan keuangan bank syariah hendaknya tidak semata-mata mendasarkan keputusannya berdasarkan kinerja yang diukur dari income statement saja tetapi juga syari'ate value added statement.

Keterbatasan penelitian ini yang mungkin mempengaruhi hasil adalah: 1) jumlah Unit Usaha Syariah yang dijadikan sampel penelitian, yaitu hanya 10 UUS dari 22 UUS yang terdaftar di Bank Indonesia. 2) belum ada konsep nilai tambah syariah yang baku, sehingga konsep yang diajukan peneliti mungkin bias. Sehingga untuk penelitian mendatang hendaknya: 1) menambah jumlah sampel UUS sehingga sampelnya lebih representatif; 2) menggunakan konsep nilai tambah syariah yang lebih terukur sehingga hasilnya lebih valid. 


\section{DAFTAR PUSTAKA}

Adityawarman, M.Amrullah, R.P.T. 2014. Analisis Perbandingan Kinerja Bank Syariah Menggunakan Pendekatan Nilai Tambah dan Laba Rugi. Diponegoro Journal of Accounting. Vol.3, No.2, hal 1-9.

Alharby, Ahmad. 2015. Development of Islamic Banking System. Journal of Islamic Banking and Finance 3 (1): 12-25.

Ari, Setyaningsih dan S.S. Utami. 2013. Perbandingan Kinerja Keuangan Bank Syariah dan Bank Konvensional. Jurnal Ekonomi dan Kewirausahaan. Vol.13, No.1, hal. 100-115.

Bastian, Indra dan Suhardjono. 2006. Akuntansi Perbankan. Edisi 1. Jakarta: Salemba Empat

Baydoun, N., dan Willet, R. 2000. Islamic Corporate Report. ABACUS 36 (1): 71-90.

Damastuti, Isnaini Endah. 2010, Analisis Perbandingan Kinerja Keuangan Bank Syariah dengan Menggunakan Income Statement Approach dan Value Added Approach. Fakultas Ekonomi Universitas Diponegoro.

Fauzi, Muchamad. 2012. Analisis Perbandingan Kinerja Keuangan Bank Syariah Dengan Menggunakan Income Statement Approach dan Value Added Approach. Jurnal Fokus Ekonomi. Vol.7 No. 2 Desember 2012: 58-79.

Harahap, Sofyan S. 2006. Menuju perumusan Teori Akuntansi Islam. Jakarta: Pustaka Quantum.

Kartika P, Putri. 2013. Analisis Kinerja Keuangan Bank Muamalat Indonesia dengan menggunakan Pendekatan Laba Rugi dan Nilai Tambah (Survei Pada PT Bank Muamalat Indonesia). Jurnal Ekonomi dan Kewirausahaan Vol. 13, No. 2, Oktober 2013: 193-203.

Kurniasari, W. 2015. Analisis Perbandingan Kinerja Keuangan Perbankan Syariah Bank Umum Syariah (BUS) dan Unit Usaha Syariah (UUS) pada Bank Umum Konvensional. Jurnal Muqtasid, Volume 6, No.1, Juni 2015. Hal. 81-103.

Marie, Atea., A. Nasser dan M.Ibrahim. 2013. Operational, Profitability, Quality Performance of Dubai's Bank: Pararel Data Envelopment Analysis. Journal of Management Research, 12 (1): 25-34.

Muhammad. 2005. Manajemen Bank Syariah. Yogyakarta: TrustMedia.

Mulawarman, A.D., Iwan, T dan Unti L., 2006. Rekonstruksi Teknologi Integralistik Akuntansi Syariah: Syariah Value Added Statement. Prosiding Simposium Nasional 9 Padang. 
Mulawarman, A.D. 2009. Akuntansi Syariah: Teori, Konsep dan Laporan Keuangan. e- publishing, Jakarta.

Raharjo, Budi. 2007. Keuangan dan Akuntansi. Yogyakarta: Graha Ilmu.

Ratmono, D. 2004. Pengungkapan Islamic Value dalam Laporan Keuangan Bank Syariah Menurut Paradigma AS Filosofis-Theoritis dan PSAK 59. Prosiding Simposium Nasional Sistem Ekonomi Islam II. PPBEI, Universitas Brawijaya Malang.

Rifai, Agus. 2013. Analisis Perbandingan Kinerja Keuangan Bank syariah Menggunakan Pendekatan Income Statement (ISA) dan Value Added Reporting (VAR).

Otoritas Jasa Keuangan. Statistik Perbankan Syariah Indonesia. 2015.

Setyaningsih, Ari dan Utami Setyaningsih S. 2013. Analisis Perbandingan Kinerja Keuangan Perbankan Syariah Dengan Perbankan konvensional, Jurnal Ekonomi dan Kewirausahaan, Vol. 13, No. 1, April 2013: 100-115.

Nadia, S., M. Sonia and B.R. Jaleleddine. 2014. Ethical Performance of Islamic Banks: The Case of the Tunisian Banking "Zaytuna. Journal of Islamic Banking and Finance, Vol.3, No.1, pp: 107-122.

Triyuwono, I. 1997. “Akuntansi Syariah"dan Akuntansi Koperasi Mencari Bentuk dalam Bingkai Metafora Amanah. Jurnal Akuntansi dan Auditing Indonesia, Vol. 1, No 1: 3-46

Triyuwono, I. 2000a. “Organisasi dan Akuntansi Syariah”. Yogyakarta:LKIS.

Triyuwono, I. 2000b. Akuntansi Syariah: Implementasi Nilai Keadilan dalam format Fenomena Amanah. Jurnal Akuntansi dan Auditing Indonesia, Vol. 1, No 1: 1-34

Triyuwono, I. 2002. Sinergi Oposisi Biner: Formulasi Tujuan Dasar Laporan Keuangan Syariah: Journal of Islamic Economics. Vol 4, No.1.

UU No.21 tahun 2008. Perbankan Syariah.

Wahyuni, Sri. dan Iwan, F. 2008. Analisis Faktor-faktor yang Mempengaruhi Sustainability Ratio Perbankan Syariah di Indonesia. Laporan Penelitian LPPM UMP

Wahyuni, Sri. 2013. The Factors that Affecting Sustainability Ratio Islamic Banking during the Global Financial Crisis: Empirical Evidence from Indonesia. Prosiding Seminar International. UIN Kalijaga. 
Weston, J.F dan T. E. Copeland. 1998. Theory and Corporate Policy. AddisonWesley Publishing Company.

Wiranti, Wahyuni. 2014. Analisis Komparatif Kinerja Keuangan Bank Syariah Berdasarkan Income Statement Approch dengan Value Sdded Statement Pada Bank Syariah Mandiri Di Indonesia. eJournal Ilmu Administrasi Bisnis, 2014, 2 (1): 30-40.

Yudistira, D. 2004. Eficiency in Islamic Banking: an Empirical Analysis on Eighteen Banks. Islamics Economics Studies, 12 (1): 1-19. 